\title{
GOD'S KNOWLEDGE OF OTHER MINDS
}

\section{DAN O'BRIEN}

Oxford Brookes University

\begin{abstract}
This paper explores one aspect of God's omniscience, that is, his knowledge of human minds. In $\$ 1$ I spell out a traditional notion of divine knowledge, and in $\$ 2$ I argue that our understanding of the thoughts of others is a distinct kind of knowledge from that involved in knowledge of the physical world; it involves empathizing with thinkers. In $\$ 3$ I show how this is relevant to the question of how, and whether, God understands the thoughts of man. There is, we shall see, some tension between the alleged direct nature of God's intuition-based knowledge and the empathetic nature of understanding others.
\end{abstract}

\section{OMNISCIENCE}

According to a conception of God derived from St. Anselm, God is the greatest being that can be conceived - that 'than which nothing greater can be thought' (Anselm 1077-8: 93). He is the omni-God: omnipotent, omnibenevolent and omniscient. His omniscience is expressed in various ways: his knowledge is 'as complete as it is possible for a state of knowledge to be' (Morris 1991: 84); 'in God there exists the most perfect knowledge' (Aquinas ST, 1a, 14, I) and God has the 'best possible knowledge in the best possible way' (Rogers 2000: 71). It can also be expressed more technically: since perfect knowledge must involve knowing everything, then it must be the case 'that, for all $p$, if $p$, then God knows that $p$ ' (Kenny 1979: 10). Variations on this theme include: 'for every proposition an omniscient being either knows it or knows it to be false' (Zagzebski 2007: 262); God 'knows of every true proposition that it is true' (Swinburne 1977: 162); an omniscient being 'knows every true proposition and believes no false ones' (Plantinga and Grim 1993: 267), and ' $\mathrm{f}$ ] or any $x$, and for any proposition $p, x$ is omniscient if and only if if it is true that $p$, then $x$ knows that $p^{\prime}$ (Nagasawa 2008: 7). 
God knows all truths about the physical world, about tables and chairs, and neutrinos and quarks - 'he looks to the ends of the earth and sees everything under the heavens' (Job 28:24). ${ }^{1} \mathrm{He}$ also knows all truths about minded individuals; 'before him no creature is hidden, but all are open and laid bare to the eyes of him with whom we have to do' (Hebrews 4:13); 'whether you hide what is in your hearts or reveal it, God knows it all' (Qur'an 3:28) - 'The Lord knoweth the thoughts of men' (Psalm 93:11). ${ }^{2}$ God knows, for example, that I live in the UK and that I grow asparagus. And, if God is omniscient he must also know that I am thinking certain thoughts - that I believe Alice Coltrane played the harp and that I covet my neighbour's Bosch chainsaw. He also knows the meaning of the words that I utter: he understands me when I say 'the asparagus is fresh' since the fact that I am referring to a certain state of affairs with those words is a fact about me, a speaker, a part of the world - and God knows all p. 'For there is not a word in my tongue, but, lo, O LORD, thou knowest it altogether' (Psalm 139:4). ${ }^{3}$

Don Cupitt, however, argues that God's omniscience should not be seen in this way; it should not be 'understood as if there were a superintelligence of infinite capacity, its memory stocked with all true propositions' (1980: 85). The Bible never represents God as knowing what everybody else knows; God is only interested in what is hidden, in mysteries and in practical wisdom; the sacred texts of the Abrahamic religions do not explicitly state that God knows all $\mathrm{p}$.

God's business [rather] is with sifting, discerning, weighing in the balance, searching out and discriminating, because God is judge, and judges have to know the whole truth in order to pass just judgment. God is only interested in religiously-relevant knowledge, not knowledge in general ... God's knowledge is always, and above all, knowledge of

\footnotetext{
${ }^{1}$ I assume that such accounts of God's omniscience - those that constitute part of the definition of the 'God of the philosophers' - are attempts to express the nature of God as described in the sacred texts of the Abrahamic religions. Part of my motivation for the claims below concerning God and empathy come from attempting to align an account of God's omniscience with the relationship that God is taken to have with man in those texts.

${ }^{2}$ See also Luke 12:2-3: 'For there is nothing covered, that shall not be revealed; neither hid, that shall not be known. / Therefore whatsoever ye have spoken in darkness shall be heard in the light; and that which ye have spoken in the ear in closets shall be proclaimed upon the housetops.'

${ }^{3}$ It is thus suggested that God is omniscient with respect to the semantic content of human languages. My argument, though, focuses on the conceptual content of thoughts. I shall not consider here the relation between semantic content and conceptual, cognitive content.
} 
mysteries and secrets. It is always knowledge of things men do not know, do not want to know, do not want to become publicly known, or do not yet know. (ibid.)

It should be noted, though, that Cupitt has an anti-realist conception of God. God is not seen as a being, but rather as 'a unifying symbol that ... personifies and represents to us everything that spirituality requires of us' (ibid.: 9). Omniscience is thus understood in terms of self-knowledge and the searching of our own hearts. I shall not consider this kind of anti-realist approach, although it may be interesting to explore how my claims below concerning empathy could relate to this Cupittian account. Empathetic understanding of others - and even of oneself at other times - could be a requirement of the spiritual life. ${ }^{4}$

Others claim that knowledge of certain trivial truths is beneath God's dignity: ${ }^{5}$ it is not demanded of God that he know the number of objects on my desk or nails in my garage. God's knowledge can be perfect even though it does not encompass such inventories. ${ }^{6,7}$

I shall not discuss here whether God's knowledge should be seen as limited in such ways since even on these accounts it is still the case that God must have knowledge of minds, at least of some minds, some of the time. Even though, for example, there may be certain thoughts that are too trivial to be the concern of God - whether I believe I am running short of $25 \mathrm{~mm}$ nails - there are other thoughts, those of religious significance, that are his concern.

${ }^{4}$ See n10. I thank Professor Beverley Clack for this suggestion.

5 There is, however, some tension here since in places scripture does suggest that God has knowledge of trivial facts: 'Are not two sparrows sold for a farthing? And one of them shall not fall on the ground without your father / But the very hairs of your head are all numbered' (Matthew 10:29-30; see also Luke 12:6-7). And in the Qur'an (6:59) it is stated that 'He has knowledge of all that land and sea contain: every leaf that falls is known to Him. There is no grain of soil in the darkest bowels of the earth, nor anything green or sear, but is recorded in a glorious Book'.

${ }^{6}$ This is a neo-Platonist view. See R. Sorabji, Philosophy of Commentators 200-600 AD: A Sourcebook (London: Duckworth, 2004); Alexander [of Aphrodisias], On Providence 13: 14-17, 25: 1-16.

7 It has also been argued that there are other limits to God's omniscience. Swinburne claims that God is not omniscient with respect to the future, and this is consonant with certain passages of scripture where God is seen to change his plans and make conditional promises (see Swinburne 1977: 177). Scripture, though, if taken literally, suggests wider gaps in omniscience: 'the LORD god called unto Adam, and said unto him, where art thou?' (Genesis 3:8) and at Genesis 18 God has to go to Sodom to check for himself what has occurred there. 
God's omniscience is not only seen in quantitative terms - in terms of God knowing all $p$, or all religiously-relevant $p$ - but also in terms of the manner in which he has such knowledge. God does not acquire his knowledge via observation or inference, but directly - by intuition. One way to think of such intuition is to consider our knowledge of (simple) a priori truths. That $2+2=4$ is something of which I am immediately aware; I do not have to infer this is true. My knowledge of this truth is, if you like, Godlike - it cannot be improved upon.

[W]ith regard to those few [truths] which the human intellect does understand, I believe that its knowledge equals the divine in objective certainty, for here it succeeds in understanding necessity, beyond which there can be no greater sureness. (Galileo, cited in Craig 1987: 19)

It is easy to see how this analogy can be extended to God's knowledge of complex mathematical truths. He is immediately aware that complex equations are true just as we are capable of seeing that $2+2=4$. And such knowledge extends to empirical and metaphysical matters. Causal relations are seen as 'intelligible', that is, it is possible for a powerful intellect or God to work out - a priori - or 'see', the effects that follow from particular causes: ${ }^{8}$ God can intuit, before the cue ball is hit, the resting position of all the balls after a snooker break. He also has intuitive knowledge of metaphysical necessities such as that water consists of $\mathrm{H}_{2}$ 0. This is one aspect of what Edward Craig (1987: Ch. 1) calls the Image of God hypothesis; our certainty with respect to a priori truths is akin to God's certainty with respect to all truth: all $p$ are directly present to his consciousness.

Some also argue that God's knowledge should not be seen as propositional; his thoughts are not 'broken up into proposition-sized bits' (Alston 1986: 288). God does not know, one, that Dan covets the chainsaw, two, that water is $\mathrm{H}_{2} \mathrm{O}$, and three, that neutrinos can travel faster than the speed of light. The alternative is to see God's knowledge as 'a seamless whole, an undifferentiated intuition of all there is' (ibid.). This is the view of Augustine, Aquinas and Anselm. According to Aquinas God has divine simplicity, thus ruling out the complexity of propositional structure. Thus, 'God does not ... analyse reality into various separate facts, each of which is internally complex, and then organize them into some kind of system.' (ibid.)

\footnotetext{
${ }^{8}$ This is a conception of our knowledge of causality against which Hume inveighs.
} 
He knows what can be enunciated, not after its manner, as if in His intellect there were composition or division of enunciations, but $\mathrm{He}$ knows each thing by simple intelligence, by understanding the essence of each thing (Aquinas ST, 1a, 24, 14).

A feature of the propositional conception of divine thought that is seen as problematic is its representational nature. Propositions represent things out in the world. But, Alston (1986: 293) argues:

[a] creature in our condition needs inner representations in order to be able to think about absent states of affairs, since the facts are rarely if ever directly present to our consciousness. But since God enjoys the highest form of knowledge $\mathrm{He}$ is never in that position, and so He has no need for inner representations that He can 'carry around with Him' for use when the facts are absent. The facts are never absent from His awareness.

One aspect of the picture that Alston rejects is cognitive internalism: the content of thought wholly determined by inner mental items. One could, however, reject this and see God's knowledge as externalist in character the content of divine thought determined by the relation between God and the objects he is thinking about. Such accounts, though, can still be seen to hold to a propositional account of thought: a thinker's cognitive relation to the chainsaw constituting a different thought (or proposition) to that constituted by his cognitive relation to Alice Coltrane. Alston's suggestion is thus more radical. It calls for not just a rejection of inner representations, but all representations. One way to think of this is to see all of God's knowledge as knowledge by acquaintance: God's openness to the whole of reality akin to our openness to sensory input. Sellars' (1956: VIII, 32-6) myth of the given, however, casts a shadow over such a picture, but this will not be explored here.

Another problem with a non-propositional conception of divine thought is that it is not clear how God's knowledge can encompass the colour of the sky and of Himalayan poppies without 'the seamless whole' of God's knowledge somehow involving something like the concept BLUE that applies to those parts of the world, but not, say, to Brazilian football shirts and primroses; nor how God's knowledge can encompass the colour of the sky and Mary's belief about the colour of the sky without somewhere in this 'whole' there being two constituents sharing something like the propositional content, the sky is blue. As, however, I am focusing on the omni-God tradition, I shall not press these objections; I shall simply assume that God's thought is propositional since that is part of 
the traditional picture, the claim being that if $p$, then God knows that $p$. God has knowledge of all (or all religiously-relevant) true propositions.

Various arguments focus on the alleged incompatibility between God's omniscience - in particular his omniscience with respect to human thought - and his other divine attributes. If God is to know everything there is to know about my thinking he must know that I believe it is now rather cold and that it looks rather pleasant over there. Knowledge of human thought involves indexical knowledge, yet God, not being located at a particular point in space and time, cannot have such knowledge. Omniscience with respect to the mind could also encompass what someone will come to think or intend or believe, and there are problems associated with God's foreknowledge of our mental actions and human free will. There are also several related arguments to the conclusion that God's divine attributes limit his possession or understanding of certain concepts. God cannot understand the concepts of surprise, tiredness, lust, fear or despair because he cannot be surprised (since he is omniscient), tired, fearful or despairing (because he is omnipotent) or lustful (because he is without sin). A common approach is to conclude from such incompatibility arguments that the omni-God cannot exist. ${ }^{9}$

This, though, is not my strategy. My starting point is a picture of God's knowledge in which he has knowledge (of at least some) of our thoughts and that this knowledge is propositional. I aim in what follows to highlight tensions within this picture, specifically between the direct, intuition-based nature of his knowledge and necessary aspects of what it is to have knowledge of other minds (the topic to which we turn in the next section) and I will thus suggest that we need to rethink how we should conceive of God's omniscience.

\section{THE EPISTEMOLOGICAL REAL DISTINCTION}

Descartes proposed a 'Real Distinction' between mind and body, between the two types of substance that compose human beings. Greg McCulloch (1999) calls this the 'ontological real distinction', in contrast to the 'epistemological real distinction' between the way we acquire understanding of the physical world and the way we have of coming to understand the thoughts of others. In interpreting thinkers, he claims, we must empathize with them: understanding someone's words,

${ }^{9}$ For a useful survey of such arguments, see Nagasawa 2008: 17-73. 
thoughts and actions involves being able to think the thoughts that they entertained when they said, thought or performed them.

Support for this claim can be found in Collingwood's (1946) account of historical knowledge. For him, history is constituted by the thoughts of its agents; history is an investigation of mind.

The processes of nature can ... be ... described as sequences of mere events, but those of history cannot. They are not processes of mere events but processes of actions, which have an inner side, consisting of processes of thought; and what the historian is looking for is these processes of thought. All history is the history of thought. (ibid.: 215)

History should be concerned with making the actions of those in the past intelligible and this will involve appreciating their reasons for acting as they did. Further, Collingwood claims that the practice of historical investigation uses the very same methods that we use in understanding each other. 'The ... historical method is the only way I can know the mind of another'. (ibid.: 219)

If it is by historical thinking that we re-think and so re-discover the thought of Hammurabi or Solon [Babylonian king and Athenian statesman respectively], it is in the same way that we rediscover the thought of a friend who writes us a letter, or a stranger who crosses the street. (ibid.: 218)

But what are the methods of history, those that Collingwood sees encompassing the interpretation of the past and each other? ${ }^{10}$ Empathy plays a crucial role. We empathize with historical figures through 'reenacting' their various predicaments and simulating their accompanying mental states.

When I understand what Nelson meant by saying 'in honour I won them, in honour I will die with them', what I am doing is to think myself into the position of being all covered with decorations and exposed at short range to the musketeers in the enemy's tops, and being advised to make myself a less conspicuous target ... Understanding the words means thinking for myself what Nelson thought when he spoke them ... Unless I were capable - perhaps only transiently - of thinking that for myself, Nelson's words would remain meaningless to me. (Collingwood 1939: 112)

${ }^{10}$ Collingwood also sees self-knowledge as derived via a historical and therefore empathetic approach: 'it is only by historical thinking that I can discover what I thought ten years ago, by reading what I then wrote, or what I thought five minutes ago, by reflecting on the action I then did' (1946: 219). 
These examples suggest a rich empirical account of the psychology of understanding others, one involving make-believe or simulation. Such details, though, need not concern us here; it is only the bare bones of the empathetic account of understanding upon which my argument depends. To see what these are, and to see why empathy is essential for understanding, I shall turn to Quine and McCulloch.

Quine focuses on what he calls radical translation: the coming to understand utterances and thoughts of an alien community from scratch. All we have to go on is the behaviour of the native speakers. And this, he claims, is also true of our understanding of each other. Radical translation highlights the nature of all understanding. In communicating with one another all we have to go on is the behavioural evidence. And:

In general the underlying methodology of the idiom of propositional attitudes contrasts strikingly with the spirit of objective science ... $[\mathrm{W}] \mathrm{e}$ project ourselves into what, from his remarks and other indications, we imagine the speaker's state of mind to have been, and then we say what, in our language, is natural and relevant for us in the state thus feigned ... [W] hat is involved is evaluation, relative to specific purposes, of an essentially dramatic act. (Quine 1960: 218-9)

As the native utters 'gavagai' we consider what we would have said if we were him. ${ }^{11}$ We may perhaps have been drawn to utter 'rabbit' - given that there's a cute furry creature in front of him - and so we forward this as a translation of his utterance. To check whether this is a good translation we can try out 'gavagai' in other situations in which we take 'rabbit' to be appropriate. If signs of approval are elicited from the natives, then we will make a start on our translation manual; if not, then 'rabbit' would be rejected and further empathetic acts would have to be attempted.

Following McCulloch, let us consider the home case in which we come to understand an utterance made by someone of our own linguistic community. As we interpret the words of a friend we do not just ascertain that he makes a certain noise: 'ra - bit'. Rather, we interpret him as saying that a rabbit is over there. One must understand what the speaker means by 'rabbit'. In order to interpret the thoughts of a thinker we must

${ }^{11}$ It is not required that, in empathizing with another, we become another (in some sense). As Hume says concerning empathy in the context of his account of moral judgment: 'No force of imagination can convert us into another person' (1772: 234). Rather, we imagine what we would say or feel if we were in the position of someone else, if we had their character and beliefs, and we could see what they see. 
understand the content of the propositional attitude ascriptions that we make. And, '[o]nly if I can understand your words in your way can I gain full-blooded understanding of you as a subject of propositional attitudes' (McCulloch 1999: 34). Similarly with respect to the natives: to ascribe propositional attitudes to them, we must come to understand 'gavagai' in the way that they do. When one has, one can then go about finding expression for this in one's home idiom. One understands and then one translates. The 'true measure of understanding is the view from inside, not the take-home message' (ibid.: 42).

As John McDowell puts it, one cannot come to understand others from 'side-on'; it is not the case that:

when we work at making someone intelligible, we exploit relations we can already discern between the world and something already in view as a system of concepts within which the other person thinks; so that as we come to fathom the content of the initially opaque conceptual capacities that are operative within the system, we are filling in detail in a sidewayson picture - here the conceptual system, there the world - that has been available all along, though only in outline. It must be an illusion to suppose that this fits the work of interpretation we need in order to come to understand some people. (1994: 34-5)

There is therefore an important distinction between how we attempt to understand each other and how we attempt to understand the physical world, and it is empathy that grounds this distinction. When interpreting a physical system we work 'from the outside', applying concepts we already understand to the observational evidence. In order to interpret the mental states of a thinker, however, we must attempt to instantiate the very intentional make-up that she is manifesting. Folk psychology is, in Quine's words, an 'essentially dramatic idiom' (1960: 219).

Quine, however, is an eliminativist with respect to meaning and content. He argues - via the indeterminacy of translation (1960: Ch. 2) and the inscrutability of reference (1990: 50-2) - that the objective, extensional evidence available to the radical interpreter cannot provide a determinate interpretation of the native's thoughts. There is thus nothing propositional in the mind there to be known. Empathy may provide us with interpretations, but these do not have scientific status and thus they do not pick out real features of the mind. One can, though, as McCulloch does, reject Quine's sceptical conclusions whilst keeping his insight with regards to empathy. 
Other-understanding ... involves not just understanding their words in their way, but also the ability to use those words in their way, as vehicles of self-expression. So ... if I am to fully understand you as a subject of propositional attitudes, then I standardly have to be able to deploy a dramatic idiom, to go in for the kind of self-expression (at least in make-believe) that you are capable of. It is a matter of getting inside your thinking by imagining and then saying how it is for you, which involves acquiescing (at least in make-believe) in your words as you acquiesce in them. Otherwise, I at best have objectifying knowledge of you as a dealer in objects that happen to be words, and at worst substitute my own usage and thinking for yours. (McCulloch 1999: 35)

In order to be able to understand another it is required that an interpreter appreciates how thoughts are taken as reasons for action and subsequent thought. To 'get inside my thinking' you need to appreciate which beliefs of mine are currently driving my behaviour - that, for example, concerning the cutting-power of the Bosch, not the difficulty in buying new chains - and how my actions and thought follow from the norms of rationality and perhaps my idiosyncratic twists on these norms. Further, you may not take the design of the handguard as adding to the saw's desirability, but to understand me you must come to appreciate how I would do so - you must understand how beliefs can be reasons for me. ${ }^{12}$ Thus, to have knowledge of what another is thinking one must be able to think thoughts with the same content as theirs - 'understand their words in their way'.

This is the core of the empathetic account upon which I shall focus. My conclusions concern the essential nature of the understanding of others. ${ }^{13}$ They concern what this must consist in for you, me, and for everyone, including God. My strategy would not therefore be accepted by those with an apophatic conception of God, by those who claim that we cannot provide any positive account of the nature of God's understanding and knowledge. ${ }^{14}$ It should be stressed, though, that I am not claiming that God must understand us in just the same way as we

12 See Stueber's arguments from the essential contextuality and indexicality of thoughts as reasons (2006: 155-65).

13 This may strike one as odd given that my thoughts are developed from those of Quine who rejects the notion of the a priori and of necessary truths. Full-blooded Quineans, however, can take my claims not to be a priori or necessary, but to be those that are deep within our web of belief, far from the periphery where claims can be tested against experience. 
understand each other, by, say, literally observing our gesticulations and hearing what we say. And it may be true that there are possible worlds in which we have very different ways of coming to understand each other; perhaps worlds where there is telepathy - an ability to which we shall return below. But my claim is that, whatever particular mechanisms may be involved, understanding others must always involve empathy, given the broad account of empathy with which I am working.

I have, then, made certain very general claims about knowledge of other minds $(\$ 2)$ and the divine mind $(\$ 1)$. The question that now arises is whether this empathetic conception of the knowledge of minds is compatible with the intuition-based model we have of the divine mind, and it is this I shall go on to discuss.

\section{GODESE}

God does not speak or think in English and so, if we accept that divine thought is propositional, then we must see it as involving concepts of a divine language; we can think of God as thinking in Godese. And, since he thinks in Godese and we think in English, we are natives to him. He is thus required to empathize with our thought in order to understand us. ${ }^{15}$

God should not though be seen as in the radical position that Quine describes. He has access to more evidence for interpretation than we do with respect to the native. We only have the behavioural evidence to go on whereas God knows the states of our brains and/or the states of our spirits when we think our thoughts, and he has this knowledge, not through inference, but via intuition - but this, I shall argue, is problematic.

When interpreting the natives we listen to their utterances, but there is nothing about a certain noise ('gav-a-guy') that carries with it its own

${ }^{14}$ Demea, the mystic in Hume's Dialogues concerning Natural Religion, claims that: 'we ought never to imagine, that we comprehend the attributes of this divine Being, or to suppose, that his perfections have any analogy or likeness to the perfections of a human creature. Wisdom, thought, design, knowledge; these we justly ascribe to him; because these words are honourable among men, and we have no other language or other conceptions, by which we can express our adoration of him. But let us beware, lest we think, that our ideas any wise correspond to his perfections, or that his attributes have any resemblance to these qualities among men.' (Hume, 1779: 44) - 'Great is the Lord, and greatly to be praised and his greatness is unsearchable.' (Psalm 145:3)

${ }^{15}$ It could be argued that the model of radical translation, on which I base my argument, is not appropriate since God created us. To resist this claim, though, think about our own children: we bring them into being, but sometimes we do not understand their actions or thinking, that is, until we attempt to empathize with them. 
interpretation - the reference to rabbits somehow contained in the sounds of their voices and thus directly perceptible to us; that would be imbuing noises with what Putnam calls a 'magical theory of reference' (1981: 3-5). There are no magical connections between words, mental images and the things in the world that those items are about: 'even a large and complex system of representations, both verbal and visual, still does not have an intrinsic, built-in, magical connection with what it represents.' (ibid.: 5)

In order to interpret what someone means by that utterance we have to see how the word 'gavagai' is used and come to be able to think the thoughts that elicit such utterances. And just as there is nothing about the sound 'gav-a-guy' that wears its meaning on its sleeve, there is also nothing about certain brain or spirit states that does either. God too, therefore, must be able to think the thoughts that elicit utterances in our languages. God must be able to think the thoughts that I am entertaining when I say that 'Alice's harp-playing is transcendent' and that 'Paul's chainsaw is powerful. ${ }^{16}$

It is not clear, though, how this is possible - how God, that is, could directly, via intuition, come to be able to think our thoughts. As McCulloch puts it, in the context of the native, this would only be possible:

if we found self-announcing ideas-of-rabbits in the skull ... But we know we shan't find any of them ... These items would not only need to constitute the alien's understanding of her words, but also, on inspection as it were, transmit it to the Outsider. What an idea! (McCulloch 1999: 41)

But this is an idea that permeates the history of philosophy and theology. It is there in both scholastic accounts of divine thought and in early modern accounts of thought and reasoning.

Aquinas claims that angels can read human minds, and they can do this much like we do ourselves - only better - that is, via behaviour: 'more deeply they penetrate those occult bodily manifestations' $(S T, 1,57,4)$ that reveal our thoughts. They do not, however, reason to the conclusion

\footnotetext{
${ }^{16}$ For the purposes of this paper I wish to remain neutral on the metaphysics of mind. My claims concerning empathy apply whether one is a dualist or a materialist of either a reductivist or non-reductivist stripe. Even if there were, for example, a plausible naturalistic account of thought, God could not read off the content of our minds via direct intuitions of the particular causal laws involved. Interpreting thought involves making the thinker intelligible - in their terms - and this, I have argued, requires empathy. 'A unified account of neuroscientific explanations of every single bodily movement of some person does not constitute a biography' (Sandis 2011: 193).
} 
that we are (for example) happy from observation of our smiles; they do not, first, observe behaviour and then infer that mental states are the cause of it. Rather, angels see or intuit our mental states as if through the behaviour: 'as an object and its image are seen simultaneously in a mirror' $(S T, 1,58,3) .{ }^{17}$

$\mathrm{He}$ also claims that angels have the ability to know our secret thoughts, those without bodily manifestation. This ability, though, cannot be exercised because 'what is proper to God does not belong to the angels. But it is proper to God to read the secrets of hearts, according to Jer. 17:19, "The heart is perverse above all things, and unsearchable; who can know it? I am the Lord, Who search the heart"' (ST, I, 57, 4). Ockham has a similar story. Angels have the power to read each other's minds and those of humans - directly, via intuition (I. Q6) - but again there is the claim that only God can 'scrutinize hearts' (IV, Q9); angels only being able to do this when God wills they can. Thus, the scholastics accept that God can read our minds and he can do this via something like perception, albeit telepathic perception. And, in a recent paper, Torin Alter 'see[s] no reason to doubt that God could directly perceive the contents of human consciousness - by telepathy' (2002: 9).

A 'perceptual model' of knowledge is also a theme in early modern philosophy. The Cartesian picture is that our mind is transparent to ourselves - to our inner eye - and thus we have complete and infallible knowledge of our own mental states. Craig argues that such knowledge is another aspect of the Image of God hypothesis: the knowledge we have of our own mental states akin to God's knowledge of reality (above we noted how our a priori knowledge is seen as akin to divine knowledge). This is also a conception of the divine mind to which Newton was committed.

17 Ockham, in contrast, argues that angels reason in much the same way we do, they infer that we have thoughts from our behaviour. There are, though, problems in accounting for this ability. There are various ways it has been claimed that we can have knowledge of other minds, but none of these look to be available to angels. I could infer that your smile indicates happiness since this is so in my own case. Angels, however, do not have bodily manifestations of mental states. A theoretical account of the mind would also be difficult to attribute to angels since on such accounts our knowledge of our own mind piggy-backs on knowledge of others (see Sellars' Myth of Jones, 1956: 90-117) and it would be difficult to accept that angelic self-knowledge depends on knowledge of a theory concerning human thought. We can also come to know what someone else is feeling (and thinking) via sympathetic mechanisms - such as those involved in the contagiousness of smiles and yawns - but again, it is not clear how these could be relevant to angels. 
We perceive images - 'sense data' in twentieth century parlance - in our 'sensorium' (Cartesian theatre) and our intimate relation with such images provides us with certain knowledge of them; God's sensorium, Newton claims, is space.

[God] sees the things themselves intimately, and thoroughly perceives them, and comprehends them wholly by their immediate presence to himself; of which things the Images only carried through the Organs of Sense into our little Sensoriums, are there seen and beheld by that which in us perceives and thinks (Newton 1704: III, 1, 20).

God's knowledge of minds is presumably of the same order. Our thoughts are immediately present to him; he 'thoroughly perceives them, and comprehends them wholly by their immediate presence to himself'. ${ }^{18}$

The immediacy of God's knowledge may not be seen as obviously incompatible with empathetic understanding. This is because it would seem we can have something akin to intuitive knowledge of other minds. We do not infer that someone is in pain when they are writhing on the floor, and we do not normally infer what someone means from the words that they utter; rather, pains are seen in their movements and meanings are heard in their utterances. McCulloch talks of phenomenological facts being available to the interpreter. God, then, having knowledge of all $p$ would know such facts and thus understand our thoughts.

Such facts, though, are not straightforwardly observable, aspects of thinkers that are just there to be seen by anyone looking, like perhaps the colour of their hair. They are the kind of facts that become manifest when one adopts the perspective of the thinker; when one manages to empathize with their thought. And so talk of phenomenological facts and of seeing pains and hearing meaning is no less problematic for conceptions of the divine mind. It is not clear how God can come to know such facts through intuition, conceived as some kind of purely perceptual ability; knowledge of such facts requires empathy. ${ }^{19}$

${ }^{18}$ Reasoning is also seen in perceptual terms in the early modern period. Locke, for example, sees reason as essentially perceptual: we directly perceive the evidential connections between ideas (both deductive and inductive). Hume can be seen as rejecting such a conception of reason, replacing it with a mechanistic account (see Millican 2012).

${ }^{19}$ It could be claimed that God could empathize with human thought through Christ. There are, though, philosophical problems with the incarnation, and any such strategy would merely seem to transpose the difficulties in understanding from between God and man - how can he understand us? - to between God and Christ. I shall not explore these issues here. 
If God is to understand our thoughts the divine mind must be more active; he must empathize with our thinking - think our thoughts for himself. If God does have telepathic abilities then such abilities - if they are to constitute understanding - must involve God coming to have thoughts with the same content as ours. Divine mindreading cannot be purely perceptual. That would involve a picture in which our minds contain magical world-directed symbols, and this is untenable.

Science can be said to adopt a God's eye view; it attempts to describe the world sub species aeternitatis. In $\$ 2$ we saw that Quine argues that mind and meaning do not come into focus from this elevated perspective; they are thus not real constituents of nature. He is a sceptic with respect to the content of language and thought. McCulloch sees such scepticism as a reductio of the assumption that all truths must be accessible to the God's eye view, and he develops a positive picture of how empathy must be involved in understanding others. The dispute between Quine and McCulloch concerns a metaphorical reading of this God's eye perspective whereas the considerations of this paper are concerned with a literal reading: just as Quine argues that the mind cannot be apprehended by the God's eye view of science, I argue that there are problems in accounting for how the mind can be apprehended by the detached perspective of God - God, the actual being. ${ }^{20}$

The problem here is distinct from that concerning knowledge de se. Certain incompatibility arguments focus on the indexical nature of some beliefs: I have the belief that $I$ covet the chainsaw, not just that somebody does - and, the argument goes - not even God can come to have such knowledge since God cannot be me. ${ }^{21}$ My argument, however, does not focus on indexical thoughts, but on thoughts that can be shared by various thinkers. Many of us can believe that Bosch chainsaws are objects of desire, but the question that concerns us here is how God can come to understand that this is the content of our belief.

Perhaps the picture must be something more like the following. Divine intuition must involve God coming to see through our eyes, somehow inhabiting our mind and having first-hand experience of

20 There is some scriptural support for the claim that God cannot understand evil thoughts - thoughts that would be incompatible with his omnibenevolence - and some theists defend the notion of divine impassibility, where God cannot experience (or understand) human negative emotions and suffering. My concerns, though, are wider; they focus on tensions in the picture of the divine understanding of all human thought.

${ }^{21}$ See Grim 1985. 
our mental states. (A picture perhaps suggested by Qur'an 50.16: 'God is close to man, nearer to him than his jugular vein.') Whether this is illuminating, though, depends on just how such a picture is understood. It would not be enough for God just to be acquainted - even from the inside - with our thoughts. This is the core of Wittgenstein's rejection of Cartesianism. God's knowledge of human thought should not be seen as akin to God having an access-all-areas pass to our private Cartesian theatres, reading off the meanings of the symbols he finds paraded there. 'If God had looked into our [Cartesian] minds he would not have been able to see there whom we were speaking of' (1953: II, 185). Such a picture of thought is still magical, however closely God is acquainted with our minds. If God somehow inhabited our mind and was acquainted with the mental states there, he would not - from such acquaintance alone be able to ascertain the content of our thoughts.

The purpose of this paper is to highlight tensions in a common picture of the divine mind, one that forms part of the conception of the omni-God. God is seen as having propositional thought and as knowing every true proposition, and he is able to have such knowledge via direct intuition. I have argued, though, that in the context of God's knowledge of other minds, this picture seemingly adheres to an unacceptable magical theory of reference. I suggest, then, that we need to think more carefully about the model of the divine mind and particularly about how God can have knowledge of our minds. And we need to get this right because much of religious significance depends on such knowledge. In order for God to be able to help us, answer our prayers, guide us, judge us and forgive us he must be able to understand our thoughts. Further, as John Kvanvig (1986) argues, to be unconditionally loved by God requires that nothing is hidden from him. My suggestion, then, is that empathy needs to be included in the picture of the divine mind. ${ }^{22,23}$

${ }^{22}$ Rogers also suggests that some kind of empathy needs to be included in our picture of the divine mind: 'As a movie-goer I can appreciate the gangster's joy in the violence which expresses his personal power and freedom without literally doing the things he does and without (I hope) incurring the guilt that, were he a real human being, he would incur. I can understand, and in a sense even share, his feelings, without being him or even being at all like him. Perhaps God is the perfect audience, able to understand and appreciate our feelings fully, without becoming us or becoming like us' (2000: 88-9). It is not clear, though, how such empathy is possible without God in some sense becoming like us.

${ }^{23}$ Thanks to audiences at the Minds: Human and Divine conference in Munich, the British Philosophy of Religion conference in Oxford, the philosophy research seminar 


\section{BIBLIOGRAPHY}

Alter, T. 2002. 'On Two Alleged Conflicts between Divine Attributes', Faith and Philosophy, 19: 47-57

Alston, W. 1986. 'Does God Have Beliefs?', in Religious Studies, 22: 287-306

Anselm, St. 1077-8. Proslogion, in Complete Philosophical and Theological Treatises of Anselm of Canterbury, trans. J. Hopkins and H. Richardson (Minneapolis: Banning Press, 2000)

Aquinas, T. 1265-74. Summa Theologica, ed. by T. McDermott (Notre Dame, IN: Ave Maria Press, 1989) [ST]

Collingwood, R. G. 1939. An Autobiography (Oxford: Clarendon Press)

Collingwood, R. G. 1946. The Idea of History (Oxford: Clarendon Press)

Craig, E. 1987. The Mind of God and the Works of Man (Oxford: Clarendon Press)

Cupitt, D. 1980. Taking Leave of God (Norwich: SCM Press)

Grim, P. 1985. 'Against Omniscience: The Case from Essential Indexicals', Noûs, 19: $151-180$

Hume, D. 1772. Enquiry concerning the Principles of Morals, ed. by L.A. SelbyBigge, rev. P.H. Nidditch (Oxford: Clarendon Press, 1975)

Hume, D. 1779. Dialogues concerning Natural Religion, ed. by N. Kemp Smith (Edinburgh: Thomas Nelson, 1947)

Kenny, A. 1979. The God of the Philosophers (Oxford: Clarendon Press)

Kvanvig, J. 1986. The Possibility of an All-Knowing God (London: Macmillan Press Ltd.)

McCulloch, G. 1999. 'From Quine to the Epistemological Real Distinction', European Journal of Philosophy, 1: 30-46

McDowell, J. 1994. Mind and World (Cambridge, Mass: Harvard University Press)

Millican, P. 2012. 'Hume's "Scepticism” about Induction', in A. Bailey and D. O'Brien, eds., The Continuum Companion to Hume (London: Continuum), pp. $57-103$

Morris, T. 1991. Our Idea of God (Notre Dame, IN: University of Notre Dame Press)

Nagasawa, Y. 2008. God and Phenomenal Consciousness (Cambridge: Cambridge University Press)

Newton, I. 1704. Opticks: or, A Treatise of the Reflections, Refractions, Inflections and Colours of Light (Oxford: W. Innys, 1730)

Ockham, W. 1991. Quodlibetal Questions, trans. A.J. Freddoso and F.E. Kelley (New Haven, CT: Yale University Press)

at Oxford Brookes, and to Bev Clack, Yujin Nagasawa, Stephen Boulter, Tim Chappell, and Daniel de Haan for help and encouragement with the paper. This paper was originally presented in Munich, at a conference for the Analytic Theology Project, generously funded by the John Templeton Foundation. 
Plantinga, A. and P. Grim. 1993. 'Truth, Omniscience, and Cantorian Arguments: An Exchange', in Philosophical Studies, 71:267-306

Putnam, H. 1981. Reason, Truth and History (Cambridge: Cambridge University Press)

Rogers, K. 2000. Perfect Being Theology (Edinburgh: Edinburgh University Press)

Quine, W. V. O. 1960. Word and Object (Cambridge, Mass: MIT Press)

Quine, W. V. O. 1990. The Pursuit of Truth (Cambridge, Mass: Harvard University Press)

Sandis, C. 2011. 'A Just Medium: Empathy and Detachment in Historical Understanding', Journal of the Philosophy of History, 5: 179-200

Sellars, W. 1956. Empiricism and the Philosophy of Mind (Cambridge, Mass: Harvard University Press, 1997)

Stueber, K. 2006. Rediscovering Empathy: Agency, Folk Psychology, and the Human Sciences (Cambridge, Mass: MIT Press)

Swinburne, R. 1977. The Coherence of Theism (Oxford: Oxford UP)

Wittgenstein, L. 1953. Philosophical Investigations, ed. G. E. M. Anscombe, R. Rhees \& G. von Wright (Oxford: Blackwell)

Zagzebski, L. 2007. 'Omniscience', in The Routledge Companion to Philosophy of Religion, ed. C. Meister and P. Copans (London and New York: Routledge), 261-269 